\title{
PCNA-related progressive neurodegenerative photosensitivity syndrome
}

INSERM

\section{Source}

INSERM. (1999). Orphanet: an online rare disease and orphan drug data base. PCNArelated progressive neurodegenerative photosensitivity syndrome. ORPHA:438134

PCNA-related progressive neurodeg enerative photosensitivity syndrome is a rare neurodegenerative disease caused by homozygous mutations in the PCNA gene and characterized by neurodegeneration, postnatal growth retardation, prelingual sensorineural hearing loss, premature aging, ocular and cutaneous telangiectasia, learning difficulties, photophobia, and photosensitivity with evidence of predisposition to sun-induced malignancy. Progressive neurologic deterioration leads to gait disturbances, muscle weakness, speech and swallowing difficulties and progressive cog nitive decline. 